\title{
Writing in L2: Norwegian Students' Use of Translanguaging at the Draft Stage
}

Marina Prilutskaya

Nord University

marina.prilutskaya@ nord.no

https://orcid.org/0000-0002-8804-7721

\begin{abstract}
This study explores Norwegian students' use of translanguaging at the draft stage of writing in English (L2). 78 drafts were written under a translanguaging writing condition, that is when the students were prompted to alternate languages during the draft stage of writing as a scaffolding technique before producing a final product in English. Thirty-seven drafts containing language alternation were analyzed using the proposed integrated framework of translanguaging and written code-switching. The analysis showed that the students' uses of translanguaging range from a strategic juxtaposition of linguistic elements fulfilling certain socio-pragmatic functions, to highly flexible language alternation with the aim of generating content or experimenting with one's linguistic repertoire. The findings reported in this paper point to the fact that the integrated framework of translanguaging, pragmatic code-switching, and language mixing may be necessary to account for the students' diverse and complex use of translanguaging in writing as it allows for a more differentiated approach to study the written form(s) of translanguaging. The present study aims to further translanguaging as an alternative pedagogy to contest the English-only approach to writing instruction in Norway because it provides the students with an opportunity to demonstrate a unique set of skills that remains obscured in the traditional monoglossic writing context.
\end{abstract}

Keywords: translanguaging, pragmatic code-switching, language mixing, linguistic repertoire, integrated framework 


\section{Introduction}

This paper reports on a study of Norwegian first-year upper secondary school students' use of translanguaging at the draft stage of writing an essay in English, their L2 ${ }^{1}$. I collected 78 drafts written under a translanguaging writing condition, that is when the students were given a prompt (see Appendix) to alternate languages during the draft stage of writing as a scaffolding technique before producing a final product in English. This definition of translanguaging is based on its original conceptualization as a pedagogical language alternation practice used to promote students' literacy development in one or more languages (Williams, 1994, 1996).

Out of 78 drafts, 37 (47\%) contained language alternation and were analyzed using the proposed integrated framework of translanguaging and written code-switching. Different ways of conceptualizing code-switching have led to the divergence of the code-switching research paradigm from the translanguaging paradigm. While acknowledging a certain degree of overlap between code-switching and translanguaging, many scholars are concerned with elucidating the differences between the two constructs (García, 2009; García \& Li Wei, 2014; Slembrouck \& Rosiers, 2017). More specifically, researchers often stress that code-switching is first and foremost a linguistic term invoking its structuralist heritage, whereas translanguaging is grounded in a broader sociolinguistic and ecological approach, not least as a pedagogy of language and an antidote to the monolingual norm and ideology in language classrooms and beyond (García \& Kano, 2014; García \& Wei, 2014; Jonsson, 2017; Lewis, Jones \& Baker, 2012; Paulsrud, Rosén, Straszer, \& Wedin, 2017).

So far, the pedagogical potential of the written form of translanguaging in mainstream multilingual classrooms has received scant attention in the literature (Canagarajah, 2011; Velasco \& García, 2014). Among recent studies that adopt a translanguaging perspective on bilingual writing development is Velasco \& García's (2014) investigation of young bilingual writers' use of translanguaging as a writing strategy in the planning, drafting, and production stages of writing. The authors qualitatively examined five writing samples produced by the

\footnotetext{
${ }^{1}$ English is in the process of becoming a second language in Norway (Rindal \& Piercy, 2013). However, English may be a foreign language (or L3) for some of the participants who did not report their proficiency in Norwegian (See Table 1). For simplicity, I use the "L2" abbreviation to refer to both FL and L2.
} 
K-4th grade Spanish-English and Korean-English bilingual students. The analysis showed that the young writers used translanguaging to organize ideas related to the topic and to engage the reader. In addition, translanguaging was employed as a vocabulary learning strategy (text annotations) and a discourse feature (internal speech). Canagarajah (2011) adopted an ethnographic, predominantly process-oriented approach to study a Saudi-Arabian graduate students' use of translanguaging as she was developing her academic writing skills in English. Canagarajah introduced the term codemeshing to refer to "the realization of translanguaging in texts" (p. 403) and reported on a positive effect of codemeshing on the student's writing process and products in terms of raised metalinguistic awareness, increased creativity, and ability to make conscious attempts to improve her writing. Other studies that address translanguaging in writing (García \& Kano, 2014; Turnbull, 2019) involved participants engaging in oral translanguaging in the planning/preparation stage of writing in a target language, that is when participants could discuss the topic and/or plan their essays using L1 or a combination of languages before writing a text in English. However, to the best of my knowledge, no previous study offers a focused investigation of the discourse-related aspect of written translanguaging in L2 writing.

In this study, I propose to synthesize the translanguaging and code-switching research paradigms to examine the students' use of translanguaging in writing. This paper seeks to fill a knowledge gap in research on written translanguaging by arguing for the utility of the sociolinguistic perspective in research on code-switching in answering the call for more empirical research on translanguaging as a writing strategy and pedagogy in multilingual language classrooms. The main aim of the paper is (i) to lay the groundwork for an integrated framework of translanguaging and written code-switching and (ii) to demonstrate the utility of the integrated approach in enhancing our understanding of how Norwegian L2 learners may employ their linguistic resources at the draft stage of writing in English.

As stated earlier, this investigation focuses on the analysis of language alternation patters in the student's drafts. Drawing on the work by Alvarez-Caccamo (1998), I employ the term "language alternation" in a broad sense to denote the alternating use of two or more recognizable linguistic varieties that may or may not carry discourse meaning and thus function as an intended contextualisation strategy (Auer, 1999). In other words, the term 


\section{Nordic Journal of Modern Language Methodology}

keeps "the notions of communicative code and linguistic variety separate" (Alvarez-Caccamo, 1998, p. 38) allowing for the possibility to switch the communicative intend (code) with or without a switch to another language (dialect, register, style, prosodic register). The opposite is also possible, i.e. the change in a linguistic form may not necessarily signify an intended discourse function.

I begin with a theoretical exploration of the origins of translanguaging and codeswitching as well as the relationship between the two concepts. The remaining part of the paper is concerned with the empirical investigation of the students' translingual writing. The analysis is based on the integrated framework of translanguaging and written code-switching proposed in the theory section of the paper. According to this framework, code-switching that serves as a contextualization cue (Auer, 1999) may constitute one manifestation of translingual practice (Canagarajah, 2013) under the umbrella term of translanguaging since the latter encompasses "a variety of discursive and pedagogical practices" (Cenoz, 2017) and can be understood as "the general communicative competence of multilinguals" (Canagarajah, 2011, p. 403).

\section{Translanguaging, Code-switching, and Language Mixing: Towards an Integrated Framework}

The term translanguaging was conceived in an educational context by the Welsh educator Cen Williams $(1994,1996)$ to denote a planned teacher-initiated pedagogical activity based on a purposeful concurrent use of two languages within a lesson or task. For Williams, translanguaging is a valuable strategy that should be encouraged and utilized in bilingual language classrooms to promote children's development in both languages. Since then the term has been further developed by a number of scholars (Creese \& Blackledge, 2010; García, 2009; García \& Kano, 2014; García \& Li Wei, 2014; García \& Otheguy, 2014; Jonsson, 2017; Lewis et al., 2012; Li Wei, 2018; Otheguy et al., 2015; Paulsrud et al., 2017) to refer to a wide range of complex language behavior in multilingual speakers in and outside of the educational context. Consequently, translanguaging evolved into an open-ended construct (Slembrouck \& Rosiers (2017), which may accommodate diverse bilingual practices, including codeswitching (García, 2009). 


\section{Nordic Journal of Modern Language Methodology}

Despite observable commonalities between pedagogical translanguaging and classroom code-switching (Lewis et al., 2012), code-switching studies have been criticized for supporting the dual competence perspective on bilingual proficiency since "codes" imply the separation of linguistic systems (García \& Otheguy, 2014; Otheguy et al., 2015). In the next section, I show that in the sociolinguistic approach to code-switching the understanding of "codes" as separate linguistic systems has been reexamined by a number of scholars.

As a response to the critique of code-switching for supposedly promoting the dual competence model, MacSwan (2017) points to ample literature on bilingualism and codeswitching $^{2}$ that adopts the holistic perspective on bilingualism to account for high levels of complexity, systematicity, and creativity involved in language alternation. A comprehensive account of the dual versus so-called "unitary" view of the architecture of bilinguals' language system(s) is beyond the scope of the paper (for a debate of the issue in question see MacSwan (2017) and Otheguy, García \& Reid (2018). Instead, building on the commonalities between the two research traditions, I propose to conceptualize pragmatic code-switching as one possible realization of translanguaging since both are rooted in the holistic view on bilingualism and, importantly, endorse and promote multilinguals' diverse language practices. The analysis of the translingual writing presented in this paper shows that the students choose to employ their linguistic repertoire in a flexible fashion, i.e. as a continuum ranging from intended juxtaposition of linguistic codes to achieve a certain discourse effect (pragmatic code-switching) to hybrid language practices devoid of such juxtaposition. Therefore, an integrated framework offers a more differentiated, data-driven approach to the analysis of the students' use of their linguistic repertoire at the draft stage of writing in a target language.

In the remaining part of this section, I lay out the premises of the integrated framework of pragmatic code-switching and translanguaging in light of different interpretations of "codes".

Code-switching has been studied since the 1950s. Jakobson, Fant \& Halle, (1952), Fano (1950), and Fries \& Pike (1949) first introduced the notion of "switching codes" as a scientific phenomenon to refer to the coexistence of phonemic systems in the mind of a monolingual or bilingual speaker. A later definition of code-switching as an alternation

\footnotetext{
${ }^{2}$ See MacSwan (2017) for the overview of studies.
} 
between languages (dialects, styles, etc.) stems from early studies on bilingualism (Weinreich, 1953; Haugen, 1956; Mackey, 1962) that focus on a systematic description of bilingual speech with the purpose of mapping linguistic choices of bilinguals. In order to predict when, how, and why the switch to another language would occur at least two distinct "codes" had to be identified. A "code" became synonymous with a language (and/or a language variety) and thus was reified by the analyst in actual speech data.

A different, interactional, approach in research on language alternation in speech was introduced and developed by Gumperz $(1957,1964)$ who looked into the social functions of code-switching, i.e. code-switching was studied in relation to the enactment, maintenance, and deconstruction of communicative roles and social identities. The interactional approach to code-switching resulted in the framework of socio-pragmatic functions of oral code-switching (McClure, 1981; Gumperz, 1982; Poplack, 1980; Valdés-Fallis, 1976). A more detailed account of this framework and its application to the analysis of written code-switching is given in the "Analytical framework" section.

The interactional approach to code-switching marked an important shift from the structural to the interpretive perspective with the starting point in meaning rather than structure. The latter requires linguists to regard a speaker's and/or listener's interpretation of language alternation in conversation as a point of departure. In this connection, AlvarezCáccamo (1998) challenges the way code-switching research often presupposes the existence of at least two distinct codes in bilingual conversation, each used to fulfill a particular pragmatic function whereas numerous examples of bilingual data contain language alternation that is perceived by the participants and linguists as virtually functionless. Instances of socalled "unmarked" or "free switching" were labeled as such and have not been explicitly addressed in the literature. With this in mind, Auer (1998) points out that a more appropriate approach to the analysis of data containing language contact entails establishing function rather than codes, i.e. functionally meaningful transitions should be labeled "code-switching", whereas those not exhibiting any clear pragmatic intention on the part of the speaker, may be referred to as instances of "mixed code". When describing "mixed code", Auer (1998) emphasizes a frequent and seamless alternation between languages or language varieties that "does not carry meaning qua language choice for the bilingual participants" and often does 


\section{Nordic Journal of Modern Language Methodology}

not "receive neither discourse- nor participant-related interpretations" (p. 16, emphasis in the original). In his later work, Auer $(1999,2014)$ employs the term "language mixing" to refer to the aforementioned type of language alternation. Auer (2014) maintains that "language mixing" should be distinguished from code-switching since, unlike code-switching, it lacks the discourse-functional aspect. The notion of "language mixing" arguably echoes some of the translanguaging definitions in the literature, for instance, "as bilingualism without diglossic functional separation" (García, 2007, p. xii), and later as a dynamic communicative practice where "languages are no longer assigned separate territories or even separate functions, but they may co-exist in the same space" (García, 2009, pp. 78-79).

Given what has been discussed so far, alternating use of languages by bilinguals appears to be much less homogeneous than a traditional understanding of code-switching entails. The last 40 years of code-switching research from the sociolinguistic perspective have shown that language alternation has properties of a continuum spanning from intentional pragmatic contrast of two codes (pragmatic code-switching) to a smooth and uninterrupted flow of language alternations in which none of the languages assumes any distinct discourse function ("language mixing") ${ }^{3}$.

Consequently, a more differentiated analytical approach is needed to grasp the diverse nature of language alternations in the students' drafts. In this approach, the designation codeswitching is reserved for the type of language alternation that carries a particular sociopragmatic function (e.g. clarification, lexical needs, quotes, parenthetical comments, etc.), while translanguaging is an overarching concept that includes all kinds of translingual practice, i.e. pragmatic code-switching, language mixing, translation, etc.

In the sections that follow, the integrated framework of translanguaging, pragmatic code-switching, and language mixing is applied to the analysis and interpretation of the students' translingual writing.

\footnotetext{
${ }^{3}$ Note that Auer $(1999,2014)$ extends the continuum further to include "fused lects" and "language fusion" as the extreme forms of language contact happening on a deeper grammatical level and resulting in new structures. Such extreme forms of language contact are not applicable to the present corpus.
} 


\section{Nordic Journal of Modern Language Methodology}

\section{Method}

\section{Participants and data}

The original corpus of 78 drafts was obtained as part of a larger study of the effect of three writing instructions on the quality of essays written by Norwegian first-year upper secondary school students (Prilutskaya, Knoph \& Hanssen, 2020). A total of 288 first-year upper secondary school students (age 15-16) from two mainstream schools in Norway received a task to write a fantasy narrative essay in English. The participants were assigned randomly (on a class-by-class basis) to one of three writing instruction groups: English-only, translation, and translanguaging. The students in the English-only group wrote their drafts and final essays in English; the students in the translation group were asked to write the drafts in Norwegian and then translate them into English. Finally, the students in the translanguaging group were prompted to alternate languages in their drafts before writing a final product in English. The language(s) of instruction including the writing prompts varied among the groups. English was used for the English-only condition, Norwegian for the translation condition, and a combination of Norwegian and English for the translanguaging condition (see Appendix). The drafts collected from the translanguaging group are the focus of the analysis in the present study. In addition to writing the essays, the participants in all three groups filled out an on-line questionnaire where they reported their language background and gender. The responses from the translanguaging group are summarized in Table 1:

\section{Table 1}

Language Background and Gender

\begin{tabular}{ll}
\hline Item & Responses \\
\hline Gender & 29 \\
Male & 40 \\
Female & 9 \\
Not Reported & \\
Norwegian proficiency & 0 \\
Beginner & 0 \\
Intermediate & 0 \\
Fluent & 57 \\
Native & 21 \\
Not Reported & \\
English Proficiency & \\
Beginner & 2
\end{tabular}


Intermediate $\quad 18$

Advanced 22

Fluent $\quad 17$

Not Reported 19

\section{L3 (or L4) Proficiency}

None

Beginner 15

Intermediate $\quad 11$

Advanced 2

Fluent 1

Native 4

Not Reported 20

Note: All data are self-reported.

\section{Analytical framework: from oral to written code-switching}

From the pragmatic perspective, oral code-switching was broadly divided into situational and metaphorical. The former is directly linked to the interactional context, for instance, when a speaker switches to another language to adjust to the needs of the interlocutor who might not speak a particular language. A metaphorical type of switches is a more complex phenomenon that is known to fulfill a pragmatic, emphatic, and creative function rather than being a direct response to a communicative situation. Language alternation patterns examined in the present study are of the metaphorical type since in written discourse the communicative context is established in advance, and remains uniform.

Most proposed taxonomies of metaphorical or socio-pragmatic functions of oral codeswitching include quotation, emphasis or clarification, triggered switches, stylistic switches, parenthetical comments, linguistic routines/idiomatic expressions, and lexical need switches (Valdés-Fallis, 1976; Poplack, 1980; McClure 1981; Gumperz, 1982; Zentella, 1997).

Edelsky (1986) was the first researcher who consistently applied the functional categories for oral code-switching to code-switching patterns in bilingual writing. In her comprehensive study of writing by elementary students enrolled in an English-Spanish bilingual program, Edelsky found that the children code-switched for clarification, direct quotation, ethnic group identity, emphasis, lexical variety, and because they learned a word or a phrase in that language. More recent studies of socio-pragmatic functions of written code- 


\section{Nordic Journal of Modern Language Methodology}

switching in adult bilingual writing showed that bilingual writers utilized code-switching in a similar manner (Montes-Alcalá, 2005, 2007; Losey, K. M., 2009).

As Sebba (2012) rightly points out, a number of researchers draw on the theories and analytical frameworks designed with oral code-switching in mind in their study of multilingual texts in written discourse. Use of written data to confirm hypotheses based on spoken data (mainly conversational code-switching) remains problematic since some written genres lack the interactional aspect of conversation. However, Sebba (2012) admits that Gumperz's (1982) fundamental contributions to the field of code-switching such as the notion of contextualization cues, a distinction between situational and metaphorical code-switching, and a taxonomy of discourse functions of code-switching, "are potentially applicable, and have been applied at some stage, to written language alternation" (p. 99). Further, similarly to the conceptualization of pragmatic code-switching given in the theoretical section of this paper, Sebba proposes to apply the term "code-switching" to a change in language that is meaningful and functioning as a contextualization cue for the reader, while other instances of language change should be classified as a different phenomenon. In this paper, I use Auer's notion of language mixing to describe such phenomena.

It follows then that previous empirical research on oral and written code-switching has provided the present study with a basic taxonomy of socio-pragmatic functions that is flexible, yet by no means exhaustive. It represents some of the most common functions of code-switching and thus offers a suitable starting point for examining language alternation in writing in the context that has not been explored before. The analytical procedures and the results obtained from them are described in the next section.

\section{Analysis and Results}

To begin with, I grouped the drafts written under the translanguaging condition according to the students' choice of language(s). Here the term "translanguaging" is narrowed down to refer to language alternation within a single draft to separate it from translation. Table 2 shows the students' choices of language(s) in the drafts: 


\section{Nordic Journal of Modern Language Methodology}

Table 2

Choice of Language(s)in the Drafts

\begin{tabular}{lccc}
\hline & $\begin{array}{c}\text { English } \\
\text { only }\end{array}$ & $\begin{array}{c}\text { Norwegian } \\
\text { only }\end{array}$ & Translanguaging \\
\hline $\begin{array}{l}\text { Number and \% distribution of } \\
\text { drafts }\end{array}$ & $14(18 \%)$ & $27(35 \%)$ & $37(47 \%)$ \\
Mean Word Count & 409.47 & 393.46 & 536.78 \\
\hline
\end{tabular}

As seen from Table 2, nearly half of the students chose to alternate languages in their drafts. In addition, the drafts containing language alternation were, on average, longer than those written in a monolingual mode. By definition, the translanguaging sub-corpus provided the data for the main investigation. The languages employed by the students include Norwegian (standard and a local dialect ${ }^{4}$ ), English, Swedish, French, Spanish, German, Greek, Icelandic, Japanese, and Nyanja (a Bantu language spoken in Malawi, Zambia, and other countries in Southern Africa). Using a bottom-up approach to the analysis of 37 drafts where more than one recognizable linguistic variety was present, I examined the patterns in the texts in light of the previously outlined socio-pragmatic categories of code-switching in writing. The categories were determined based on the similarity to the examples in previous studies and contextual clues present in the texts. The following categories were recognized in the corpus:

- emphasis

- direct speech, quotation

- triggered switches

- lexical need switches

- linguistic routines

- parenthetical comments

- language mixing (synonymous with "free switching" in other taxonomies)

It is necessary to point out that the instances of language mixing were handled differently from other types of alternations, i.e. instead of counting every switch of this kind as an individual case, I chose to categorize language mixing as a single type of language alternation because it was employed consistently throughout the respective drafts. In such

\footnotetext{
${ }^{4}$ In Norway, there are two official languages, i.e. Norwegian and Sami. With regard to Norwegian, two standard written varieties of it (Bokmål and Nynorsk) are taught in schools. However, there are numerous spoken local dialects that Norwegians use on a daily basis. Since there is no standard variety of spoken Norwegian, these local variations are used in most contexts (Store norske leksikon, 2019).
} 


\section{Nordic Journal of Modern Language Methodology}

cases, it was difficult to determine where one case of language mixing ends and another one begins. In order to avoid a situation when the proportion of language mixing would be artificially inflated due to the density of alternations within one text, I treated these dense language alternations as evidence of a single case of translanguaging, namely, language mixing.

The distribution of the categories (both raw frequencies and \%) that were identified in the drafts is illustrated in Figure 1:

\section{Figure 1}

\section{Distribution of Categories}

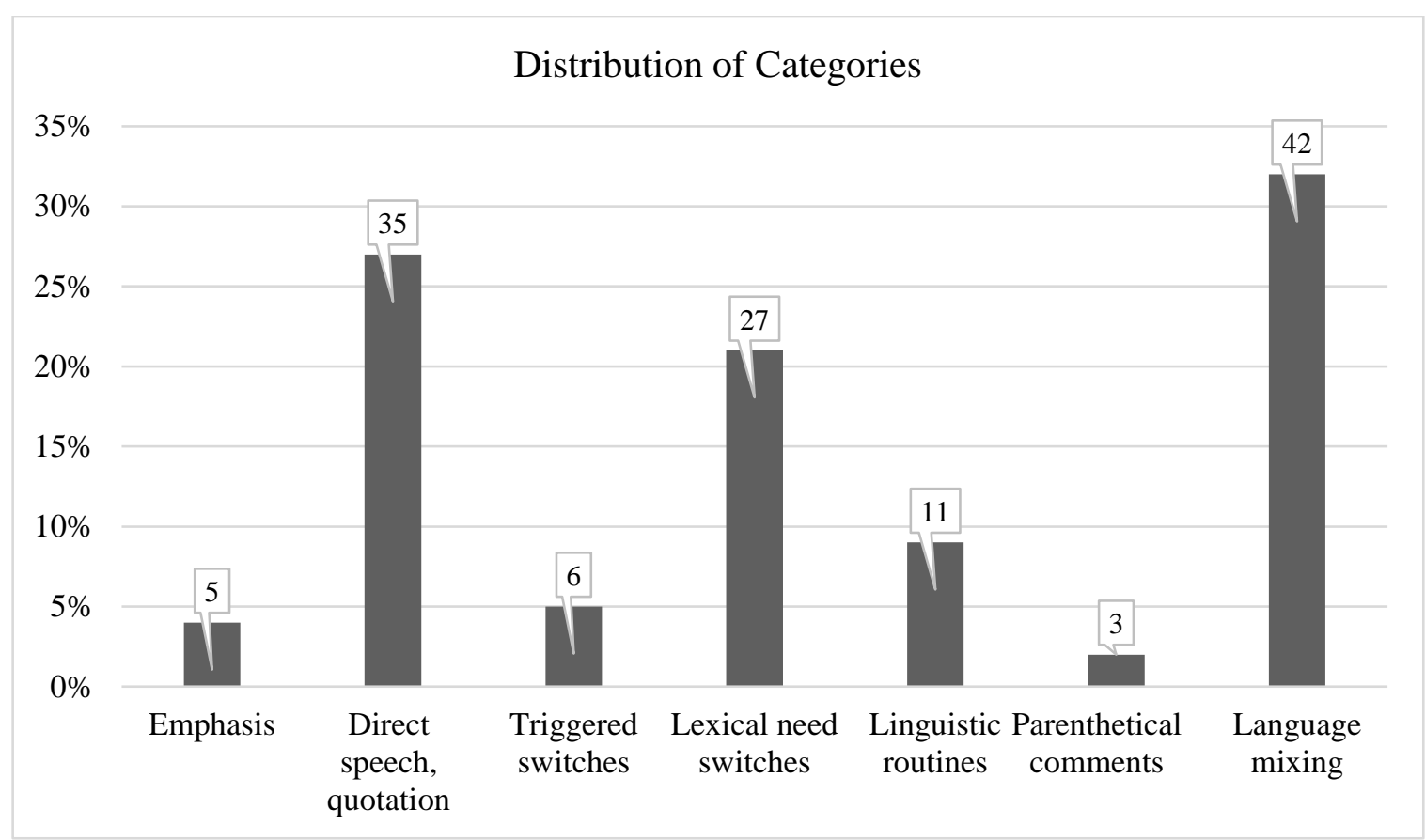

In the following subsections, I provide a brief description of the outlined categories followed by the examples from the corpus.

\section{Emphasis}

This type stands for around $4 \%$ of the total number of switches. As the name suggests, these switches are introduced to emphasize a certain idea by repeating the same or similar message in two languages. Specifically, in Example 1, the author emphasizes their fear of being alone in a big city by adding a sentence in Norwegian that further explains why the author feels intimidated by Tokyo. In Example 2, the author reinforces the image of spending three 
pleasant days in Tokyo by adding a sentence in English that summarizes the idea. In Example 3, the author underscores that fact that they don't speak any Japanese by switching to the English word whatsoever.

(1) This huge and unknown city scares me. Jeg er bare vant til lille og ufarlige X. [I am only used to small and safe $\mathrm{X}]^{5}$

(2) I de 3 dagene a ska var i Tokyo ska a gjøre ka a vil. AE ska bo på den fineste hotellet og spis ka a vil. Jeg skal kjфp masse bøker og les. [During the 3 days in Tokyo I'll be doing what I want. I'll stay at the nicest hotel and I'll eat what I want. I'll buy lots of books and I'll read a lot] The only thing I am going to do is have fun for 3 whole days.

(3) [...] jeg snakker ingen japansk, whatsoever. [I don't speak any Japanese, whatsoever]

\section{Direct speech, quotation}

This is a productive category that accounts for $27 \%$ of the switches. There is a variety of languages associated with the switches for quotation, such as, English to Spanish (Example 5), Swedish to Norwegian (Example 6), French to Norwegian (Example 7), and others. Interestingly, the students make use of the opportunity to alternate not only between the languages but also between the standard and local varieties of Norwegian as in Example 8 where the author alternates between standard Norwegian and the local dialect.

(4) "Get in the car" sier mannen med en gebrokken engelsk. ["Get in the car" says the man in broken English]

(5) Then I tried in Spanish. "Perdon, hola señorita". [Sorry, hello miss]

(6) Var är $d u$ ? spør mamma, som forresten er svensk. [Where are you? Mom asks, who is Swedish by the way]

(7) “Oui, je juste arrive á Tokyo ... ça va bien ... au revoir, tu me manque aussi". Jeg legger mobiltelefonen i vesken min og tar frem kartet. ["Yes, I just arrived in Tokyo ... it's ok ... goodbye, I miss you too". I put my mobile phone in my purse and take out the map]

(8) Mamma babler i vei om at jeg skulle ha tatt et kart og kompass kurs før jeg dro hit. Det er så typisk mamma - å stresse over alt. "Jada mamma, d går fint ... noei, a har ikke glфmt noe ... men a må gå nu mamma ... jada ... hade ...”. [Mom is jabbering on and on that I should have taken a map and compass course before I went here. It's so typical mom - to stress about everything. "Yes mom ... it's all

\footnotetext{
${ }^{5}$ All examples contain my close translation from Norwegian in square brackets, unless another base language is specified. The translated parts are intended to retain as many features of the original text as possible. Typos and misspellings that did not affect the content are corrected for clarity. Switches from a base language to a different one are in italics. In Example 1 " $X$ " is used instead of the name of the city for anonymity purposes.
} 
right... no, I haven't forgotten anything ... but I have to go now mom ... yes, bye..."]

(9) Jeg ser ut vinduet på de gigantiske bygningene, de ser enda stфrre ut narmere. Welcome to Tokyo my friend. [I look out the window at the gigantic building, they look even bigger close up. Welcome to Tokyo my friend]

(10) I remember thinking "Jeg vet jo at jeg kommer hele veien fra Norge men det er jo helt merkelig hvor mye folk endrer seg fra land til land". [I know that I come all the way from Norway but it is weird how much people change from country to country]

(11) "Hmmmm, jeg kan jo finne noe i dag og dra dit i mårra" I think to myself. ["Hmmmm, I can find something today and go there tomorrow" I think to myself]

\section{Triggered switches}

This category consists of around 5\% of the total number of switches. Triggered switches appear to be prompted by the preceding word or phrase. In this category, I found alternations between Norwegian and English. In Examples 12 and 13, the inserted English phrases seem to cause a switch, with the following text continuing to be in English. In Example 14, the direction of the triggered switch is reversed. The triggering word(s) is/are marked in bold face.

(12) Så drar jeg til "Tokyo stock exchange". There I will buy stocks in promising companies. [So I go to "Tokyo stock exchange"]

(13) Jeg spør rundt meg om det er noen som kan engelsk "You talk English??????" I ask several people, but everyone just looks at me like I'm some huge idiot. [I ask around me if anyone can speak English]

(14) Being in Tokyo, the temperatures were reasonably high, but still klarte jeg ikke å vri meg ifra frysens grep. Jeg går gjennom flyplassen, det er folk rundt meg overalt. [I couldn't escape the grip of cold. I walk through the airport, there are people everywhere around me]

\section{Lexical need switches}

Lexical switches make up a productive category with around $21 \%$ of the total number of switches. The word "need" in this context does not necessarily refer to switches due to the participants' lack of language proficiency. I could identify only three cases of what could be interpreted as a genuine lexical access problem. All three cases are from the same essay (see Example 15). The rest of the switches in this category can be ascribed to serving stylistic purposes, mainly, to enhance expressiveness. For instance, in Examples 16 and 17 the Japanese word and phrase are utilized for authenticity since the action is placed in Japan. The 
rest of the examples below illustrate how English words and expressions are employed for stylistic purposes. The students use English because it is a better fit for the message being conveyed either due to lack of an exact equivalent in Norwegian or due to the associations with the English-speaking culture. In addition, the students' stylistically motivated switches advertise the writers' intercultural competence, which is evident in the reference to the movie title and a rather habitual use of English colloquialisms.

(15) As I step out of the yellow taxi, a warm (bris) hits my face. The road is full of cars, buses and people biking, and the (fortau) is full of people. Finally, I find a site where the letters are (gjenkjennelige), and I search for the best hotel they have available. [breeze, pavement, recognizable]

(16) I will be sure to say arigato a lot.

(17) 良い一日 [“Good day” in Japanese]

(18) Kanskje, som i the inception, har du sett den? Veldi mind twisting! [Maybe like in "The Inception", have you seen it? Very mind twisting!]

(19) Ettersom jeg ikke kan språket er jeg ganske så lost in this town. [Since I can't speak the language, I'm quite lost in this town]

(20) Jeg ville ha tenkt at dette var en gylden mulighet to explore, og få nye opplevelser fra deres kultur og væremåte. [I would have thought this was a great opportunity to explore and to get new experiences from their culture and way of living]

(21) [...] kredittkorte e "limitless" så æ bare tar $\mathrm{d} æ$ vil kjøp t kassa å dræg korte. No question asked. [Credit card is "limitless" so I just take what I want to buy to the cashier of swipe the card. No question asked]

(22) Jaja, d får vi ta på "the big girl pants" ... bløh, æ hata sånne uttrykk. [Okay, on with the "big girl pants"...bløh, I hate sayings like that]

(23) De beste opplevelsene tror jeg fines hvor man kan ta et lite "step back" og ta inn alle minnene og plassene jeg hadde vert på. [The best experiences I think can be found when one can take a little 'step back' to reflect on all the memories and places I had visited]

(24) "Hva slags sykt game show er dette?" ["What sort of a sick game show is this?"]

(25) På film og tv har jeg sett mange fine parker i Japan som har veldig fine "cherry blossoms". [On film and TV I have seen many nice parks in Japan that have very nice "cherry blossoms"]

(26) Klokka var nesten halv ett da jeg stod opp, og jeg rakk definitivt ikke frokosten på hotellet. Jeg bestemte meg bare for å droppe den. Men så var det da 'mission-getclothes'. [It was almost half past twelve when I got up, and I definitely missed breakfast at the hotel. I decided to drop it. But then it was "mission-get-clothes"]

\section{Linguistic routines}

Around $9 \%$ of the total number of switches falls under this category. Linguistic routines imply use of a range of brand names, words, and phrases that are routinely used by Norwegian speakers in the original language, which is primarily English. Compared to the lexical need 


\section{Nordic Journal of Modern Language Methodology}

switches for stylistic purposed described above, linguistic routines switches are employed for convenience and thus lack a creative aspect of stylistic switches.

(27) "Hvorfor bruker du ikke bare Google translate?" ["Why don't you just use Google translate?"]

(28) Plutselig kommer vi på at vi må bestille flybillettene hjem, men når jeg skal betale, kommer det "error". [Suddenly we realize that we have to book our flight tickets home, but as I am about to pay, there is an "error"]

(29) Etter at jeg var ferdig gikk jeg ut og brukte google maps făr finne en shopping mall får å kjøpe noen klær [...]. [After I was done I went out and used google maps to find a shopping mall to buy some clothes]

\section{Parenthetical comments}

This least productive category includes three cases and amounts to around $2 \%$ of the total number of switches. The first two examples (30 and 31) come from the same essay. Here the author inserts additional information in Norwegian to clarify and expend on the message expressed in the English sentence. The parenthetical comment in (32) serves a different purpose, i.e. it functions as a mental note to remind the author to add more information to the text at a later point of time.

(30) Carpets are usually soft and nice to walk on, which is why you find them in so many places, one of those places may be Japan (a veit ikke, har ikke veert der). [I don't know, I haven't been there]

(31) Seeing how I can buy practically anything that I want (som e lovlig i hvert fall). [that is legal at least]

(32) Alle sansene som trigges. Lukten av mat; (list of foods). [All the senses triggered. Smell of food]

\section{Language mixing}

This is the most prolific category in the corpus with around $32 \%$ of coverage. Language mixing includes cases where the alternation between languages seems to be unmotivated in terms of the socio-pragmatic functions mentioned earlier. The patterns of the switches in this category vary substantially, i.e. from rather dense multiple alternations within a single phrase or a sentence (Examples 33-38) to more orderly structured patterns where the author sticks to one language per paragraph, such as in Example 41 with one paragraph written in a nonstandard French and the next one in Norwegian. Mixing more than two languages is another distinct characteristic feature of language mixing, which is illustrated in Examples 39 and 40. 
In Example 40, the author shuttles between German (in italics), Norwegian, and English (in bold), whereas Example 40 contains English, Norwegian, Spanish, and Greek.

(33) The første [first] day I wanted to se [see] the city. I hadde [had] never been $i$ [to] Tokyo before $s a ̊$ [so] although I was disappointed with the plane delay, I figured this kunne [could] be a nice opportunity til [to] enjoy meg [my] selv $i$ [in] a nytt [new] place. The first ting [thing] I did was å finne [to find] a nice hotel to leave min [my] luggage. I didn't have to travel veldig [very] far until I fant [found] a fem stjerne [five stars].

(34) I also bought a nice car and other viktige ting [important things] which I would need when I reiser dit igjen [go there again].

(35) I ankom [arrived] at the airport in Tokyo, and I fant straks the dyreste [quickly found the most expensive] hotel with the most luxury. But before I could dra til [go to] the hotel I had to leie en tolk [hire an interpreter], and I got den beste $i$ bransjen [the best one in the business]. AE kjopte [I bought] another hotel room for tolken [the interpreter], so I had access to him til enhver tid [constantly].

(36) Etter det gikk jeg til en restaurant [After that I went to the restaurant] to eat and it was deep fried everything, it was good because they fried potato, shrimp, fish, chicken, grønnsaker. [vegetables] Jeg var mett. [I was full]

(37) How was I going til å overleve her $i$ [to survive here for ] three days? I had to find a plass jeg kunne bo. [place to live] Det kunne ikke vare et problem [It could not be a problem] in a city like this. Jeg har penger og alt annet nødvendig. [I have money and everything else I need]

(38) The sounds around me are so different from what is known. I lille Norge er alt så stille a rolig [In little Norway everything is so quiet and peaceful] but here the different of sounds are all around me. From the language to the massive sound of trafikk [traffic] and alle menneskene [all the people] just walking up and down the stairs.

(39) Since ich habe ubegrenset amount of money, plan A is to pay some Japanese dude til og schreibt mein Text, so I kann bare enjoy my ferie in Tokyo. It sounds easy, but tro meg, es ist nicht. I don't give up easy, so ich turn zu plan B right away. [Since I have an unlimited amount of money, plan A is to pay some Japanese dude to write my text, so I can just enjoy my vacation in Tokyo. It sounds easy, but believe me, it is not. I don't give up, so I turn to plan B right away]

(40) I am now a billionaire and the world's richest man to ever walk the earth. Therefore I donate vast amount of money to charity. Siden jeg nå har aksjer har jeg sikret meg massiv rikdom til når jeg kommer hjem. [Since I've got shares now, I've secured massive wealth for myself till I get home] I'll buy my own personal jet. Which will take me to Switzerland. Where I will put enormous amounts of money in a secure bank. Después voy a mi casa en Noruega para vivir una vida feliz como muy rico. [Translation from Spanish: Then I go back to my house in Norway to live a life as very rich] Epipleon, tha doso stin oikogeneia mou. [Translation from Greek: In addition, I will give to my family]

(41) Day one : je voudrais visite les attractions touristiques. Après les attractions, je voudrais achète chaussures et visite louis Vuitton, Versace, Prada, Fendi, Chanel 
et achète beaucoup. [I would like to visit the tourist attractions. After the attractions, I would like to buy shoes and visit Louis Vuitton, Versace, Prada, Fendi, Chanel and buy a lot]

Day two : Æ har allerede vært i ett land som æ ikkje kan språke tel, så det e null problem å komme sæ imella de forskjellige plassan. Dag to ville også ha gått til masse luksus shopping. [I have already been to a country where I could not speak the language, so there is zero problem with getting to different places. On day two I would also do lots of luxury shopping].

In the following pages I discuss the empirical findings in light of the proposed integrated framework.

\section{Discussion and concluding remarks}

As was pointed out in the introduction, the aim of this paper was to develop an integrated framework of translanguaging and code-switching in order to explore the students' use of translanguaging at the draft stage of writing a text in English. Drawing on the theoretical discussion of this paper, I have proposed a more nuanced approach to the conceptualization of code-switching as an intended contextualisation strategy (Auer, 1999) that fulfills one or more of the socio-pragmatic functions described in the adopted analytical framework. The data analysis showed that the students utilized code-switching for reasons similar to those identified in previous research, i.e. they switched for a quote or direct speech, for emphasis, for stylistic purposes, lexical needs, and for linguistic routines. A large proportion of the switches for quotation found in the present corpus (27\%) is not surprising as switching to the original language of speech or thought helps achieve authenticity in written texts.

Furthermore, when seen through the lens of Bakhtin's notion of heteroglossia, the insertion of another language/code for emphasis and, in particular, for direct speech and quotation adds a new dimension to the discussion of the students' use of translanguaging as a discourse strategy. The result of "incorporating intratextual discourses into the narrator's text" (Tjupa, 2009 , p. 125) is the effect of multiple voices belonging to the narrator and characters and coexisting within the fabric of a single text. The use of a "hybrid construction" (Bakhtin, 1981) or "utterance within utterance" (Vološinov, 1929/1973) allows the narrator to distance themselves from the characters by giving the characters their own voice. As Tjupa (2009) points out, "the direct speech of a character often serves to express that character's linguistic view of the world, which can differ to a greater or lesser extent from the view of the world on which the narration is based" (p.126). The effect of multiple voices (heteroglossia) is not 


\section{Nordic Journal of Modern Language Methodology}

necessarily due to the use of different national languages, i.e. in some cases (see Example 8) the students turn to their local Norwegian dialect with the same purpose of creating another voice for themselves. It is possible that this voice is a better match to their sense of identity than the standard variety of Norwegian employed in the main body of the text. Strengthening the author's identity through the use of dialects alongside the standard variety may benefit Norwegian learners who reported lacking confidence in their English writing skills (Horverak, 2015).

Next, lexical need switches, emphasis, and parenthetical comments as functional categories of code-switching in writing show the students' ability to use their linguistic repertoire both as a scaffolding strategy (word retrieval or creating a mental note to remind the writer to edit a piece of text at a later point in time) and a discourse strategy to enhance the communicative ability of their writing (emphasizing an idea or using other languages for stylistic purposes).

The categories discussed so far have a clear functional profile, and thus are indicative of pragmatic code-switching. However, the category of language mixing manifests a different phenomenon since it was not associated with any particular socio-pragmatic function. Interestingly, language mixing was the most productive category, which points to the fact that the students seem to have good command of both pragmatic code-switching and language mixing. A feasible explanation of the ample use of language mixing in the drafts was provided by the students in their answers to the on-line survey about their attitudes towards the translanguaging writing mode (Prilutskaya \& Knoph, 2020). The students explained that they alternated languages in their drafts as they tried to generate as many ideas as possible irrespective of the language of thought. Perhaps, allowing the thoughts to be expressed in whatever language available at a given moment helped reduce cognitive load and facilitate access to content schemas in long-term memory. The content schemas deliver information about the topic and content organization and thus are important in terms of coping with cognitive demands of writing in a target language. The students also noted that they incorporated other languages into their drafts to enhance stylistic and rhetorical features of the texts. According to the students' responses, being able to integrate multiple languages in their writing helped engage the reader and convey desired atmosphere. However, not every case of 


\section{Nordic Journal of Modern Language Methodology}

language mixing indicated its use as a writing strategy as three of the participants reported mixing languages due to the nature of the instruction and writing prompt as well as for the sake of experimenting with languages when given a chance to do so. With this in mind, Examples 33 and 39 may represent the task-induced artifacts rather than cases of naturally occurring language alternation since the switches often do not comply with syntactically definable constituent boundaries. The latter stands in contrast to a more commonly observed "constituent-by-constituent" pattern of switch in bilingual as well as monolingual speech production and processing (Azuma, 1996). Despite being possible artifacts of the elicitation process, these examples of language mixing may attest to the students' willingness to engage in translanguaging for the purposes of exploration, which they expressed in the survey. This demonstrates the students' openness to experiment with crosslingual writing practices in classroom settings, which in turn can be a potentially effective tool for creating engaging and stimulating learning activities that may facilitate students' ability to employ their linguistic repertoire in more innovative and learner-oriented ways.

Finally, the category of triggered switches represents a curious phenomenon, i.e. on the one hand, the switches of this nature mark clear boundaries between the languages and in this regard are unlike the dense and multiple alternations of language mixing. On the other hand, the switches are not driven by any specific socio-pragmatic function. Montes-Alcalá (2000) suggested the following explanation of triggered switches that she identified in her data:

It could well be that the sentence is already constructed in an abstract way in the mind of the speaker, before he/she knows in what language it will come out, so if a word is going to be switched later on, that could trigger a switch [...].

The cognitive processes underlying triggered switches are likely to occur at the stage of translation that in Flower \& Hayes's (1980) cognitive model of writing refers to the process of converting thoughts/ideas into symbols (written language). In this respect, triggered switches are more analogous to language mixing than pragmatic code-switching as they manifest the flexible and interconnected use of languages. However, since one can identify a trigger word or a phrase, triggered switches may occupy the middle ground between intentional switching and free language alternation. 
Overall, this study confirms that the students utilize their linguistic resources in diverse ways. Forty-one students (53\%) chose to stick to one language per draft (either English or Norwegian), even when they were prompted to draw on their background languages. The participants' monolingual preferences are compatible with the monolingually oriented context of teaching English in Norway, i.e. in addition to the English-only format of nationally administered exams, the purpose of introducing other languages to ELT is limited to fostering metalinguistic awareness between English and L1 (The Norwegian Directorate for Education and Training, 2013). Nonetheless, 37 students (47\%) demonstrated that they are in possession of an array of diverse translingual writing strategies that range from a skillful and strategic use of contrasting linguistic elements fulfilling certain socio-pragmatic functions, to highly flexible language alternations that may occur for the purposes of generating content or experimenting with one's linguistic repertoire. The findings reported in this paper point to the fact that the integrated framework of translanguaging, pragmatic code-switching, and language mixing may be necessary to account for the students' diverse and complex use of translanguaging in writing as it allows for a more differentiated approach to study the written form(s) of translanguaging. The present study aims to further translanguaging as an alternative pedagogy to contest the English-only approach to writing instruction in Norway because it provides the students with an opportunity to demonstrate a unique set of skills that remains obscured in the traditional monoglossic writing context.

Future studies should be carried out to further investigate this approach to the analysis and interpretation of the students' use of the written form(s) of translanguaging in other educational, instructional, and linguistic contexts. Further studies of the pedagogical affordances of the written form(s) of translanguaging may contribute to the expansion of student translanguaging to the domain of language assessment practices that need to accommodate the realities of multilingual classrooms in Norway and elsewhere. The findings of this investigation indicate that including student translanguaging in L2 writing instruction may be beneficial in terms of making a full range of the students' diverse use of their linguistic repertoire visible. The recently renewed version of the National Curriculum for English (LK20, The Norwegian Directorate for Education and Training, 2019) stresses the importance of promoting learners' ability to recognize multilingualism as a resource in school and in society at large. In addition, teachers are required to plan and implement diverse 
assessment practices that allow learners to demonstrate their knowledge of English in various ways and in various contexts. With this in mind, translanguaging-based writing assessment practices can offer a way of recognizing and promoting learners' dynamic use of their linguistic resources in English language classrooms.

\section{References}

Alvarez-Cáccamo, C. (1998). From "switching code" to "code-switching": Towards a reconceptualization of communicative codes. In Peter Auer (Ed.), Code-Switching in Conversation: Language, interaction, and identity (pp. 29-48). London, UK: Routledge.

Auer, P. (1998). Bilingual Conversation revisited. In P. Auer (Ed.), Code-Switching in Conversation: Language, interaction, and identity (pp. 1-24). London, UK: Routledge.

Auer, P. (1999). From codeswitching via language mixing to fused lects: Toward a dynamic typology of bilingual speech. The International Journal of Bilingualism, 3(4), 309332.

Auer, P. (2014). Language mixing and language fusion: when bilingual talk becomes monolingual. In Besters-Dilger, J., Dermarkar, C., Pfänder. S. \& Rabus, A. (Eds.), Congruence in contact-induced language change: Language families, typological resemblance, and perceived similarity (pp. 295-235). Walter De Gruyter, Inc.

Azuma, S. (1996). Speech Production Units Among Bilinguals. Journal of Psycholinguistic Research, 25(3), 397-416. http://dx.doi.org/10.1007/BF01726999

Bakhtin, M. (1981). The Dialogic Imagination: Four Essays. Austin, TX: University of Texas Press.

Canagarajah, S. (2011). Codemeshing in Academic Writing: Identifying Teachable Strategies of Translanguaging. The Modern Language Journal, 95, 401-417.

https://doi.org/10.1111/j.1540-4781.2011.01207.x

Canagarajah, S. (2013). Translingual Practice: Global Englishes and Cosmopolitan Relations. New York: Routledge.

Cenoz, J. (2017). Translanguaging in School Contexts: International Perspectives. Journal of Language, Identity and Education, 16(4), 193-198. https://doi.org/10.1080/15348458.2017.1327816

Creese, A \& Blackledge, A. (2010). Translanguaging in the bilingual classroom: A pedagogy for learning and teaching? The Modern Language Journal, 94(1), 103-115. https://doi.org/10.1111/j.1540-4781.2009.00986.x

Edelsky, C. (1986). Writing in a Bilingual Program: Había una vez. Norwood, NJ: Ablex Publishing Corporation.

Fano, R. M. (1950). The Information theory point of view in speech communication. Journal of the Acoustical Society of America, 22(6), 691-696. 
Fries, C. C. \& Pike, K. L. (1949). Coexisting phonemic systems. Language, 25(1), 29-50.

García, O. (2007). Foreword. In S. Makoni \& A. Pennycook (Eds.), Disinventing and Reconstituting Languages (pp. xi-Xv). Clevedon: Multilingual Matters.

García, O. (2009). Bilingual education in the $21^{\text {st }}$ century: A global perspective. Malden, MA and Oxford, UK: Blackwell/Wiley.

García, O. \& Kano, N. (2014). Translanguaging as Process and Pedagogy: Developing the English Writing of Japanese Students in the US. In J. Conteh \& G. Meier (Eds.), The Multilingual Turn in Language Education: Benefits for Individuals and Societies (pp. 258-275). Clevedon, UK: Multilingual Matters.

García, O. \& Otheguy, R. (2014). Spanish and Hispanic Bilingualism. In M. Lacorte (Ed.), The Routledge handbook of Hispanic applied linguistics (pp. 639-658). New York: Routledge.

García, O. \& Wei, L. (2014). Translanguaging: Language, Bilingualism and Education. New York: Palgrave Macmillan.

Gumperz, J. J. (1957). Some remarks on regional and social language differences in India. In Milton Singer (Ed.), Introduction to the Civilization of India: Changing Dimensions in Indian Society and Culture (pp. 31-38). Chicago, Ill: The College, University of Chicago Syllabus Division.

Gumperz, J. J. (1964). Hindi-Punjabi code-switching in Delhi. In H. Lunt (Ed.), Proceedings of the Ninth International Congress of Linguistics (pp. 1115-1124). The Hague: Mouton.

Gumperz, J. J. (1982). Discourse strategies. Cambridge, UK: Cambridge University Press.

Haugen, E. (1956). Bilingualism in the Americas: A Bibliography and Research Guide. Alabama: University of Alabama Press/American Dialect Society.

Hayes, J. R. \& Flower, L. S. (1980). Identifying the organization of writing processes. In L. W. Gregg \& E. R. Steinberg (Eds.), Cognitive processes in writing (pp. 3-30). Hillsdale, NJ: Lawrence Erlbaum.

Jakobson, R., Fant, M. G. \& Halle, M. (1952). Preliminaries to Speech Analysis: The Distinctive Features and their Correlates. Cambridge, Mass.: The MIT Press.

Jonsson, C. (2017). Translanguaging and Ideology: Moving Away from a Monolingual Norm. In Beth Anne Paulsrud et al. (Eds.), New Perspectives on Translanguaging and Education (pp. 20-37). Bristol, UK: Channel View Publications Ltd.

Lewis, G., Jones, B. \& Baker, C. (2012). Translanguaging: Developing its Conceptualization and Contextualization. Education Research and Evaluation, 18(7), 655-670.

Li Wei (2011). Moment Analysis and Translanguaging Space: Discursive Constructions of Identities by Multilingual Chinese Youth in Britain. Journal of Pragmatics, 43(5), 1222-1235. 
Li Wei. (2018). Translanguaging as a Practical Theory of Language. Applied Linguistics, $39(1), 9-30$.

LK20. The Norwegian Directorate for Education and Training (2019). Retrieved from https://www.udir.no/lk20/eng01-04

Losey, K. M. (2009). Written Code-switching in the Classroom: Can Research Resolve the Tensions? International Journal of Bilingual Education and Bilingualism, 12(2), 213230.

Mackey, W. F. (1962). The Description of Bilingualism. Canadian Journal of Linguistics/Revue Canadienne de Linguistique, 7(2), 51-85. https://doi.org/10.1017/S0008413100019393

MacSwan, J. (2017). A Multilingual Perspective on Translanguaging. American Educational Research Journal, 54(1), 167-201. https://doi.org/10.3102\%2F0002831216683935

McClure, E. (1981). Formal and functional aspects of the codeswitched discourse of bilingual children. In R. P. Durán (Ed.), Latino language and communicative behavior (pp. 6994). Norwood, NJ: Ablex.

Montes-Alcalá, C. (2000). Written Codeswitching: Powerful Bilingual Images. In R. Jacobson (Ed.), Codeswitching Worldwide II (pp. 193-219). Berlin: Mouton de Gruyter.

Montes-Alcalá, C. (2005). "Dear Amigo": Exploring Code-switching in Personal Letters. In S. Lotfi \& M. Westmoreland (Eds.), Selected Proceedings of the Second Workshop on Spanish Sociolinguistics (pp. 102-108). Somerville, MA: Cascadilla Proceedings Project.

Montes-Alcalá, C. (2007). Blogging in Two Languages: Code-Switching in Bilingual Blogs. In Jonathan Holmquist et al., (Eds.), Selected Proceedings of the Third Workshop on Spanish Sociolinguistics (pp. 162-179). Somerville, MA: Cascadilla Proceedings Project.

Otheguy, R., García, O. \& Reid, W. (2015). Clarifying Translanguaging and Deconstructing Named Languages: A Perspective from Linguistics. Applied Linguistics Review, 6(3), 281-307. http://dx.doi.org/10.1515/applirev-2015-0014

Otheguy, R., García, O. \& Reid, W. (2018). A Translanguaging View of the Linguistic System of Bilinguals. Applied Linguistics Review, 10(4), 625-652. https://doi.org/10.1515/applirev-2018-0020

Paulsrud, B., Rosén, J., Straszer, B. \& Wedin, Å. (2017). Perspectives on Translanguaging in Education. In Beth Anne Paulsrud et al. (Eds.), New Perspectives on Translanguaging and Education (pp. 10-19). Bristol, UK: Channel View Publications Ltd.

Poplack, S. (1980). Sometimes I'll Start a Sentence in Spanish y Termino en Espanõl: Towards a Typology of Code-switching. Linguistics, 18(7/8), 581-618. 
Prilutskaya, M. \& Knoph, R. (2020). Research on Three L2 Writing Conditions: Students' Perceptions and Use of Background Languages When Writing in English. Cogent Education, 7(1). https://doi.org/10.1080/2331186X.2020.1832179

Prilutskaya, M., Knoph, R., \& Hanssen Allen, J. (2020). Use of Students’ Linguistic Resources in Teaching English as an Additional Language in Norway. Manuscript submitted for publication.

Rindal, U \& Piercy, C. (2013). Being "Neutral"? English Pronunciation Among Norwegian Learners. (Report). World Englishes, 32(2), 211-229.

Sebba, M. (2012). Multilingualism in written discourse: An approach to the analysis of multilingual texts. The International journal of Bilingualism, 17(1), 97-118.

Slembrouck, S. \& Rosiers, K. (2017). Translanguaging: A Matter of Sociolinguistics, Pedagogics or Interaction? In Van Avermaet, P., Slembrouck, S., Van Gorp, K., Sierens, S. \& K. Marijns (Eds.), The Multilingual Edge of Education (pp. 165-187). London, UK: Palgrave Macmillan. http://dx.doi.org/10.1057/978-1-137-54856-6_8

Språk i Norge. Store norske leksikon. Retrieved from https://snl.no/spr\%C3\%A5k_i_Norge

Tjupa, V. (2009). Heteroglossia. In P. Hühn, J. Pier, W. Schmid, \& J. Schönert (Eds.), Handbook of Narratology (pp. 124-131) (2 ed., De Gruyter Handbook). Walter De Gruyter.

The Norwegian Directorate for Education and Training (2013). Retrieved from https://www.udir.no/in-english/

Turnbull, B. (2019). Translanguaging in the planning of academic and creative writing: A case of adult Japanese EFL learners. Bilingual Research Journal, 42(2), 232-251. https://doi.org/10.1080/15235882.2019.1589603

Valdés-Fallis, G. (1976). Social Interaction and Code-switching Patterns: A Case Study of Spanish-English Alternation. In Gary Keller et al. (Eds.), Bilingualism in the Bicentennial and Beyond (pp. 86-96). New York: Bilingual Press.

Velasco, P. \& García, O. (2014). Translanguaging and the Writing of Bilingual Learners. Bilingual Research journal, 37(1), 6-23. https://doi.org/10.1080/15235882.2014.893270

Vološinov, V. N. (1929/1973). Marxism and the Philosophy of Language [Original publication in Russian, 1929, English translation by L. Matejka \& I. R. Titunik, 1973] Cambridge, MA: Harvard University Press.

Weinreich, U. (1953). Language in Contact. The Hague: Mouton.

Wiliams, C. (1994). Arfarniad o ddulliau dysgu ac addysgu yng nghyd-destun addysg uwchradd ddwyieithog [An evaluation of teaching and learning methods in the context of bilingual secondary education] (Unpublished PhD thesis). University of Wales, Bangor, UK. 
Williams, C. (1996). Second Education: Teaching in the Bilingual Situation. In C. Williams, G. Lewis \& C. Baker (Eds.), The Language Policy: Taking Stock (pp. 39-78).

Llangefni, UK: CAI.

Zentella, A. C. (1997). Growing Up Bilingual: Puerto Rican Children in New York. Malden: Blackwell.

\section{Appendix: Writing prompts}

\section{Translanguaging group}

You are asked to write a short essay in English, eller på norsk eller annen språk, or a blend of languages, on the following theme:

Du har akkurat ankommet Tokyo! Du har pass, telefon, kredittkort, og klærne du har på deg. Neste fly hjem går om tre dager, and you don’t speak the language, så du må klare deg selv i en stor fremmed by. Å oppholde seg på flyplassen er ikke aktuelt. Hva vil du gjøre for å skaffe deg mat, overnatting, og transport mens du er der? Hva syns du om denne opplevelsen?

\section{English-only group}

You are asked to write a short essay in English on the following theme: You have just arrived in Tokyo! You have your passport, your phone, a credit card, and the clothes on your back. The next plane home is in three days, so you'll have to stay on your own in a very big city where you do not speak the language. Staying in the airport is not an option. What steps will you take to find food, housing, and transportation while you're waiting? How do you feel about this experience? 